\title{
The Human Brain Does Not Need High Levels of Motivation to Learn a Foreign Language: Motivation Has Had its Day
}

\author{
Kieran Green \\ Osaka Dental University, Japan \\ E-mail: kieran_green@hotmail.com
}

Doi:10.7575/aiac.alls.v.7n.5p.70

Received: 14/05/2016

URL: http://dx.doi.org/10.7575/aiac.alls.v.7n.5p.70

Accepted: 22/07/2016

\begin{abstract}
Language is nature in action and something humans do. This literature review presents evidence from the literature that suggests that learning a foreign language in a classroom situation does not require high levels of student motivation. It is instead suggested that high levels of motivation are needed to make progress when a teacher is using traditional teaching methods. It is shown that all healthy human brains are excellent at learning and using language, and high levels of motivation to learn a foreign language are not required if teaching practices and materials replicate natural learning experiences, and class participation is ensured. This work is of great importance to teachers as it demonstrates that teachers would help students more by investing their time in developing class materials than by worrying about student motivation.
\end{abstract}

Keywords: foreign language, cognitive linguistics, language evolution, language learnability, language usability, motivation

\section{Introduction: motivation in foreign language learning}

Motivation connected with learning a foreign language has a 60 year research history, with the major researchers in the field all having published in the past ten years (Gardner 2007, Deci \& Ryan 2008, Dörnyei 2014). Gardner (1985) distinguished motivational drivers as instrumental goals - the practical values of speaking the target language - and integrative goals - the desire to learn the language in order to become integrated into the target language culture. In their Self-determination Theory, Deci \& Ryan (1985) divided motivational drivers into intrinsic type-doing something because it is interesting or enjoyable - and extrinsic type - doing something because it leads to a non-language outcome. While these two conceptualisations of motivation to learn a foreign language are still useful, motivation is now seen as a complex dynamic system that is constantly in flux and different for all individuals (Waninge et al. 2014). The importance of motivation in learning a foreign language has been sacrosanct; has been unquestionable. Zoltan Dörnyei (1998) stated that, "motivation has been widely accepted by both teachers and researchers as one of the key factors that influence the rate and success of second/foreign language (L2) learning," and "without sufficient motivation, even individuals with the most remarkable abilities cannot accomplish long-term goals, and neither are appropriate curricula and good teaching enough on their own to ensure student achievement. On the other hand, high motivation can make up for considerable deficiencies both in one's language aptitude and learning conditions."

Almost 20 years ago, that might have been true. However, researchers are still confounded by their largely unsuccessful attempts to motivate students in the language classroom (McEowna \& Takeuchib 2010, 2014, Thurman 2013). Some interesting work did show that is was possible to motivate students (Guilloteaux \& Dörnyei 2008), but the research methods employed were questioned (Ellis 2009) although later defended (Guilloteaux \& Dörnyei 2009). In this literature review, I seek to assess the importance of motivation for learning a foreign language by looking at how the brain learns language, how language has evolved to be learnt and assessing to what extent currently prevalent teaching methods facilitate these.

\section{Language is a naturally occurring phenomenon}

Humans did not create language; rather, language use has evolved over time (Fisher \& Marcus 2005, Hauser, Chomsky \& Fitsch 2002, Hauser et al. 2014, Maynard Smith \& Szathmáry 1995), and evolutionary studies include the anatomical (Lieberman 2007), comparison of the faculty of vocal communication with the gestures of other apes (Arbib et al. 2008) and how the evolution of vocal communication coevolved with stone tools (Stout \& Chaminade 2012). And indeed, all humans probably use language in the same way (Calude \& Pagel 2011, Fitsch 2011, Kemp \& Regier 2012), as the possible ranges of language use are restricted by what the brain can do (Christiansen et al. 2011, Chater \& Christiansen 2010a) and shaped by our common world (Perfors \& Navarro 2014), although a single set of features that is common to all languages has as yet proved elusive (Evans \& Levinson 2009).

Language is nature in action; language is something humans do. However, learning a new native language, and growing up with a widely-used second language, are very different from learning foreign languages, and in this work learning a foreign language in a classroom situation is examined.

The following section contains assessments of the work done over the past decades on how the brain learns foreign languages (for reviews on neurolinguistics see: Poeppel et al. 2012, Kemmerer 2014; for reviews on language 
acquisition see: Chater \& Christiansen 2010b, Hagen 2008, Hulstijn et al. 2014), and what the brain learns when it learns a language (for reviews of see: Ellis et al. 2015, Kirby \& Christiansen 2003, Pleyer \& Winters 2014).

\section{How the Brain Learns Foreign Languages as Relating to Teaching Methods}

Language is a natural phenomenon, but humans are not born with the ability to produce and understand language, as we are born with the ability, for example, to digest food. However, although language has no genetic basis, the physiologies that support the ability to learn and use a language do (Fisher \& Marcus 2006, Lachlan \& Feldman 2003, Poeppel et al. 2012), and they are probably adaptations of structures and competencies that existed before language (Smith \& Kirby 2008, Christiansen \& Chater 2015, Dąbrowska 2015, Deák 2014). Below is examined how the brain learns foreign languages, starting with brain function, going on to look at teaching and then learning.

Neurolinguistics. An examination of how the brain learns languages necessarily has to begin with a discussion of how the brain handles native and foreign languages. Neurolinguistics seeks to understand how the cognitive capacity for language is subserved by the biological tissue of the brain (Kemmerer 2014), and there is a substantial body of research comparing the brain activity of native speakers (L1) and users of a foreign language learnt in adulthood (L2), i.e. not bilinguals, who learnt two languages as children and are proficient in the use of both. While it is certain that learning a foreign language as an adult changes how the brain processes language (Yang et al. 2015), work examining these changes is conflicting, with some investigations showing that individuals use different brain areas if using L1 or L2 (Hefling at al. 2012, Pèrez et al. 2015), and others showing that similar brain areas are used when using either L1 or L2 (Batterink \& Neville 2013, Bowden et al. 2013, Morgan-Short et al 2012a). Additionally, the age at which a language is learnt has been shown to affect the areas of the brain that are used. Research has shown that monolingual natives and people who were late acquirers of the same language as an L2, i.e. had a different childhood native tongue, use different brain pathways when using the two languages equally proficiently (Hernandez et al. 2007, Perani et al. 2003).

Nevertheless, despite the lack of consensus about which areas of the brain are active when using an L2, it has been shown that more proficient L2 users show more native-like brain activity (Bowden et al. 2013, Clahsen \& Felser 2006, Morgan-Short et al. 2012a).

Teaching and Successful L2 Acquisition. Children in their home country reach fluency in L1 without explicit instruction by the age of 4 or 5 years, and children growing up in one country with a non-native parent who familiarizes their growing children with their native language become bilingual in a similar time (Scheffner Hammer et al. 2014). However, foreign language acquisition in a classroom is different, and the factors important in enabling a person to acquire a foreign language are discussed below.

In the classroom, a foreign language is often studied; rather than a student guessing and trying to work-out what is going on around them, or simply just using what is heard repeatedly in communicative situations. These two different modes of learning are termed explicit ('studying' in a classroom) and implicit ('picking up' the language as a result of communicating) respectively (Ellis 2015), and users who learnt their L2 implicitly exhibit more native-like activity patterns in the brains when using their L2 (Batterink \& Neville 2013, Morgan-Short et al. 2012b).

Another potential way teaching methods might differ is whether the L2 was supplied to students by their teachers as something that should be consciously memorized, like historical dates, or something that was learnt through repetition, like a sport. These different methods, namely declarative learning (explicit memorizing) and procedural learning (learning by doing many times), access different types of memory, and there is evidence to suggest that language relies much more on procedural-memory. Moreover, these different types of memory use different brain-areas, which in turn affects fluency and speed-of-recall (Morgan-Short et al. 2014). Procedural-learning via imprinting following a high frequency of hearing and using the same structures and words eliminates the need for memorizing (Diessel 2007, Gries \& Ellis 2015). Additionally, learning needs repetition as it is quite possibly nonlinear (Fisher 2008), and the brain continues organizing material long after the learning episode (Morgan-Short et al. 2012a). However, some explicit instruction and declarative-learning is beneficial in the early stages of learning an L2 (Morgan-Short et al. 2014), and implicit-learning of L2 alone is not effective (Andringa \& Rebuschat 2015, Boers et al. 2014, Kirschner et al. 2006).

Learning and Successful L2 Acquisition. Having looked at the teaching factors that determine successful L2 acquisition, presented below are learning processes that mirror how we all learnt our native language.

Guessing meaning and structure and predicting what comes next. Children learning a native language initially guess meanings, and frequently using the same words and phrases means that as the same meaning-word pairing is made more often, the meaning becomes more concrete in the mind; confidence in its meaning increases. This 'guessing' is called bootstrapping, and occurs in learning L1, both for semantics and syntax (Deacon 1997, Fisher et al. 2010, Höhle 2009). Furthermore, language is a social activity, and successful language learning needs interaction with others in the target language (Chater \& Christiansen 2010, Kuhl 2011). A large part of interacting is predicting what is going to come next - action or language — which is also important for language learning (Misyak et al. 2010), as is predicting whether the use of a certain unit of language in a particular situation is possible (Robenalt \& Goldberg 2015).

Noticing and self-correcting mistakes. Paying attention to form and structure of utterances, checking the listener's response and self-correcting mistakes aid retention and progress in L2 acquisition (Adam 2003, Mackey 2006, Schmidt 1990).

The role of reward and novelty. Stimulation with novel learning-experiences has been shown to improve learning (Sousa 2011, Tokuhama-Espinosa 2010). Much of this can be explained by the release in the brain of the neurotransmitter dopamine. Dopamine release is closely connected to novel situations (Costa et al. 2014) and reward (Baudonnat et al. 2013), and is related to learning (Puig et al. 2014) and has been shown to improve L2 learning (Wong et al. 2012, Wong et al. 2013). 


\section{What the Brain Acquires from a Language as Relating to Lesson Contents}

Two fields of investigation that can help us identify the features of a language that allows humans to learn and use it are Cognitive Linguistics and Evolutionary Linguistics.

Ideas from the Cognitive-Linguistics Framework. In the Cognitive-Linguistic paradigm-including Construction Grammar approaches, which propose that language can be defined as the knowledge of form-meaning pairings, and the Usage-Based approaches, which propose that language acquisition and processing are based on instances of actual language use-language is seen as tightly integrated with cognition as a whole (Pleyer and Winters 2014). Construction grammars propose that all levels of description using grammar rely on formulaic structures that represent form-meaning pairings being recognized and fixed in the mind, or 'cognitively entrenched', through repetition, (Hoffmann \& Trousdale 2013); Usage-based approaches state that meaning and structure emerge from use (Tomasello 2008), and that language users are sensitive to input-frequencies resulting in more frequent structures being learnt more easily and processed more fluently (Ellis et al. 2015). For both divisions within the Cognitive-Linguistic paradigm, frequency of occurrence of words and structures is important, and there is substantial evidence that the brain is highly sensitive to frequently-heard patterns in language (Alali \& Schmitt 2012, Chater \& Vitányi 2003, Corrigan et al. 2009, Ellis 2012, Ortaçtepe 2013, Serrano et al. 2014, Wray 2000, Wray 2012).

Ideas from Evolutionary Linguistics. In Evolutionary Linguistics, language is seen as a complex adaptive system resulting from the interaction of the individual learning the language, how the language has changed over history and how humans have changed through history (Pleyer and Winters 2014). The idea of language changing to be better suited to its environment is more than ten years old (Kirby \& Christiansen 2003, Brighton et al. 2005), but these ideas are currently undergoing revision due to their former reliance on ideas of an inborn, innate language template in the Universal Grammar ideas of Chomsky (1965), which are no longer a central framework theory in linguistics (Dąbrowska 2015, Evans \& Levinson 2009).

Contemporary Evolutionary Linguistics sees language as something that is learnt socially from more proficient users in a process of iterative learning (de Boer 2015, Griffiths \& Kalish 2007, Kirby et al. 2014, Kirby et al. 2015), which also has social impacts, and processes driving language change have also been referred to as cultural selection (Smith \& Kirby 2008, Steels 2011, Tamariz M. et al. 2014). This change in language can happen randomly in small populations, like randomly fluctuating gene-frequencies in genetic drift (Kimura 1968). However, selection to be better suited to the environment, like biological evolution, is a far more powerful and directional driver of change, and evolutionary linguistics sees language as changing over time to make it easier to learn and use (Croft 2008).

Learnability is defined as all individuals in a language group being able to reconstruct the same language from the all different learning experiences of the individuals in the group (Kirby \& Christiansen 2003), and the ability for the language to survive intact over many episodes of transmission (Brighton et al. 2005, Kirby et al. 2015); usability is defined as being able to describe things unambiguously, and being able to process and bring to mind language at a high enough speed to facilitate communication in real-time (Kirby et al. 2015, Hills \& Adelman 2015). While there is evidence to suggest that English has changed over the past two hundred years to be more usable (Hoffman \& Trousdale 2011) and learnable (Hill \& Adelman 2015), it has also been shown that languages evolve to be easier to use, but that this change makes them harder to learn, meaning therefore that usability is more important (Fay \& Ellison 2013). Nevertheless, it is usually considered that learnability and usability cannot continue to change independently because they will eventually trade-off at an equilibrium point (Smith et al. 2013), as a very simple, easily learnt language cannot be very expressive. It is at this equilibrium point that we see the coevolution of both as the evolution of grammar (Kirby et al. 2015), which enables more sense to be expressed in fewer words, thereby increasing the speed at which the brain can process language and making it easier to learn (Piantadosi et al. 2012). The process of language changing over time to be more learnable and useable has been used to explain semantic change (Landsbergen et al. 2010), syntactic change (Kirby et al. 2015) and vocabulary evolution (Smith 2004).

\section{Bringing together teaching methods, the natural characteristics of brains and language, and motivation}

Explicit, traditional methods of explaining language to students, which rely on declarative learning and do not repeat common formulas, such as grammar translation or present-practise-produce (PPP) methods, need a great deal of motivation, self-study and practise to develop any proficiency. This is because, as has been explained in detail above, they do not allow the language to be acquired by the brain how nature has intended it to acquire a language, nor do they allow the language to enter the brain how nature has designed it to enter the brain. However, even today in 2016, when researchers have known since the mid-90s that PPP methods are ineffective (Lewis 1996, Ritchie 2003), they are still used to teach students (Jarvis 2014), are still taught on TEFL courses as being the way to teach English to users of other languages (personal experience), and are still the core of the majority of text books currently in use across the EFL world.

Additionally, as has been discussed, increasing the motivation of foreign language students has little impact on proficiency progression (McEowna \& Takeuchib 2010, 2014, Thurman 2013), and motivation often wains through the academic year anyway (Busse \& Walter 2013). Additionally, it has been shown that extrinsic motivational drivers are much more effective than intrinsic motivational drivers at increasing student participation (Chen at al. 2005, Pae 2008, Warden \& Lin 2000, Wong 2012), which is needed in lessons for students to acquire any benefit from being present.

What is therefore needed, is a method of ensuring students participate in exercises and exercises that mimic - or even augment - how the brain acquires a language and contain language components that make that language learnable. Foreign language students retain more of what is covered in lessons and attain a higher proficiency if more implicit (Morgan-Short et al. 2014, Ellis 2015) methods are employed. Such methods are the communicative, student-centred, activity based approaches that have been suggested as superior alternatives to traditional methods since the mid-90s 
(Willis \& Willis 1996) and have been gaining momentum ever since (Oxford 2006, Skehan 2003, Littlewood 2004, Ellis 2014). These lessons give students more opportunity to create their own word-meaning and structure-meaning pairings through intention-reading and observing the reactions of communication partners, to implicitly create structural schemes from repeated experiences, to guess and experiment with meanings and structures, and to predict communicative outcomes through storytelling, role play and discussion. Clearly, as has already been discussed, some explicit classroom instruction is necessary, such as guiding students to formally classify patterns that they have used in class. However, this should only make up a small part of class time. Finally, ensuring that students participate could be effected by requiring them to submit evidence of their class work at the end of each lesson.

\section{Conclusion}

Increasing student motivation was one field of research that aimed to increase the proficiency of students in communicating in a foreign language. However, motivation in language learning loses the importance it has found in recent decades if teaching practices guarantee participation, mimic natural learning processes, and lesson contents reflect the constituent parts of a language that make it learnable and usable.

It has been shown that the human brain can do nothing but acquire a language that it uses in a natural way. This work gives firm reason that for classes of students with low motivation, teachers are better to create engaging, fun activities that repeat common linguistic structures than to try to do something about their low motivation per se.

Finally, more research is necessary in the field of language changing to become more learnable. Knowledge of the exact characteristics and contents of a particular language that make it learnable would revolutionize foreign language teaching if this knowledge were incorporated into lessons.

\section{Acknowledgements}

I would like to thank three anonymous referees for their helpful comments regarding the manuscript.

\section{References}

Adam, A. (2003) L2 Output, Reformulation and Noticing: Implications for IL Development. Language Teaching Research, 7, 347-376.

Andringa, S. \& Rebuschat, P. (2015) New Directions in theSstudy of Explicit and Implicit-learning. Studies in Second Language Acquisition, 37, 185-196.

Alali, F.A. \& Schmitt, N. (2012) Teaching Formulaic Sequences: The Same or Different from Teaching Single Words? TESOL Journal, 3, 153-180.

Arbib, M.A., Liebal, K. \& Pika, S. (2008) Primate Vocalization, Gesture, and the Evolution of Human Language. Current Anthropology, 49, 1053-1076.

Batterink, L. \& Neville, H. (2013) Implicit and Explicit Second Language Training Recruit Common Neural Mechanisms for Syntactic processing. Journal of Cognitive Neuroscience, 25, 936-951.

Baudonnat, M., Huber, A., David, V. \& Walton, M. E. (2013) Heads for Learning, Tails for Memory: Reward, Reinforcement and a Role of Dopamine in Determining Behavioral Relevance Across Multiple Timescales. Frontiers Neuroscience, 7, doi 10.3389/fnins.2013.00175.

Boers, F, Lindstromberg, S. \& Eyckmans, J. (2014) Some Explanations for the Slow Acquisition of L2 Collocations. VIAL, 11, 41-62.

Bowden, H.W., Steinhauer, K., Sanz C. \& Ullman M.T. (2013) Native-like Brain Processing of Syntax Can Be Attained by University Foreign Language Learners. Neuropsychologia, 51, 249-511.

Brighton, H., Kirby, S., \& Smith, K. (2005) Cultural Selection for Learnability: Three Principles Underlying the View that Language Adapts to be Learnable. In: M. Tallerman (Ed.) Language Origins: Perspectives on Evolution. Oxford: Oxford University Press.

Busse, V., \& Walter, C. (2013). Foreign Language Learning Motivation in Higher Education: A Longitudinal Study of Motivational Changes and their Causes. The Modern Language Journal, 97, 435-456.

Calude, A. S. \& Pagel, M. (2011). How Do We Use Language? Shared Patterns in the Frequency of Word use Across 17 World Languages. Philosophical Transactions of the Royal Society B, 366, 1101-1107.

Chater, N. \& Christiansen, M.H. (2010a). Language Evolution as Cultural Evolution: How Language is Shaped by the Brain. WIREs Cognitive Science 1, 623-628.

Chater, N. \& Christiansen, M.H. (2010b). Language Acquisition Meets Language Evolution. Cognitive Science, 34, 1131-1157.

Chater, N. \& Vitányi, P. (2003). Simplicity: A Unifying Principle in Cognitive Science? Trends in Cognitive Science, 7, 19-22.

Chen, J.F., Warden, C.A. \& Chang, H.T. (2005). Motivators That Do Not Motivate: The Case of Chinese EFL Learners and the Influence of Culture on Motivation. TESOL Quarterly, 39, 609-633.

Chomsky, N. (1965). Aspects of the Theory of Syntax. Cambridge, MA: MIT Press.

Christiansen, M.H. \& Chater, N. (2015). The language Faculty that Wasn't: A Usage-based Account of Natural Language Recursion. Frontiers in Psychology, 6, 1182. doi: 10.3389/fpsyg.2015.01182.

Christiansen, M. H., Reali, F. \& Chater, N. (2011). Biological Adaptions for Functional Features of Language in the Face of Cultural Evolution. Human Biology, 83, 247-259. 
Clahsen, H. \& Felser, C. (2006). How Nativelike is Non-native Language Processing? Trends in Cognitive Science, 10, 564-570.

Corrigan, R., Moravcsik, E. A., Ouali, H., \& Wheatley, K. M. (Eds) (2009). Formulaic Language: Volume 2 Acquisition, Loss, Psychological Reality, and Functional explanations. Amsterdam: John Benjamins.

Costa, V. D., Tran, V. L., Turchi, J. \& Averbeck, B. B. (2014). Dopamine Modulates Novelty Seeking Behavior During Decision Making. Behavioural Neuroscience 128: 556-56

Dąbrowska, E. (2015). What Exactly is Universal Grammar, and Has Anyone Seen It? Frontiers in Psychology 6: 852. doi: 10.3389/fpsyg.2015.00852.

Deacon, T.W. (1997). The Co-evolution of Language and the Brain. New York: W.W. Norton \& Co.

Deci, E. L., \& Ryan, R. M. (1985). Intrinsic Motivation and Self-determination in Human Behavior. New York: Plenum.

Deci, E.L. \& Ryan, R. M. (2008). Self-Determination Theory: A Macrotheory of Human Motivation, Development, and Health Canadian Psychology 49: 182-185

Deák, G.O. (2014). Interrelations of Language and Cognitive Development. In: Encyclopedia of Language Development. P. Brooks \& V. Kampe, (Eds) SAGE.

de Boer, B. (2015). Evolution of Speech-specific Cognitive Adaptations. Frontiers in Psychology 6, 1505. doi 10.3389/fpsyg.2015.01505.

Diessel, H. (2007). Frequency Efects in Language Acquisition, Language Use, and Diachronic Change. New Ideas in Psychology, 25, 108-127.

Dörnyei, Z. (1998) Motivation in Second and Foreign Language Learning Language Teaching 31, 117-135.

Dörnyei, Z. (2014). Future Self-guides and Vision. In: K. Csizér \& M. Magid (Eds.), The Impact of Self Concept on Language Learning (pp. 7-18). Bristol, UK: Multilingual Matters.

Ellis, R (2009). A Reader Responds to Guilloteaux and Dornyei's "Motivating Language Learners: A ClassroomOriented Investigation of the Effects of Motivational Strategies on Student Motivation." TESOL Q. 43, 105-109.

Ellis, N. (2012). Formulaic Language and Second Language Acquisition: Zipf and the Phrasal Teddy Bear. Annual Review of Applied Linguistics, 32, 17-44.

Ellis, R. (2014). Taking the Critics to Task: The Case for Taskbased Teaching Proceedings of CLaSIC 103-117.

Ellis, N. (2015). Implicit and Explicit Language Learning: their dynamic interface and complexity. In: Implicit and explicit-learning of languages. P. Rebuschat (Ed.) Amsterdam: John Benjamins.

Ellis, N. C., O'Donnell, M. B. \& Römer, U. (2015). Usage Based Language Learning. In: The Handbook of Language Emergence B. MacWhinney \& W. O'Grady (Eds) New Jersey: John Wiley \& Sons, Inc.

Evans, N. \& Levinson, S.C. (2009). The Myth of Language Universals: Language Diversity and Its Importance for Cognitive Science. Behavioural and Brain Sciences, 32, 429-492.

Fay, N. \& Ellison, T.M. (2013). The Cultural Evolution of Human Communication Systems in Different Sized Populations: Usability Trumps Learnability. PLoS ONE, 8, e71781. doi:10.1371/journal.pone.0071781.

Fisher, C. Gertner, G. Scott, R. M. \& Yuan, S. (2010). Syntactic Bootstrapping. Wiley Interdisciplinary Reviews: Cognitive Science, 1, 143-149.

Fischer, K. W. (2008). Dynamic Cycles of Cognitive and Brain Development: Measuring Growth in Mind, Brain, and Education. In: The Educated Brain A.M. Battro, K.W. Fischer, \& P.J. Léna (Eds.) Cambridge, UK: Cambridge.

Fisher, S. E. \& Marcus, G. F. (2005). The Eloquent Ape: Genes, Brains and the Evolution of Language. Nature Reviews 7, 9-20.

Finn A.S., Lee T, Kraus A., Hudson Kam C.L. (2014). When it Hurts (and helps) to Try: The Role of Effort in Language Learning. PLoS ONE, 9, e101806. doi:10.1371/journal.pone.0101806.

Fitch, W.T. (2011). Unity and Diversity in Human Language. Philosophical Transactions of the Royal Society B, 366, 376-388 doi:10.1098/rstb.2010.0223.

Gardner, R. C. (1985). Social Psychology and Second Language Learning. London: Arnold.

Gardner, R.C. (2007). Motivation and Second Language Acquisition. Porta Linguarum 8, 9-20.

Gries, S.T. \& Ellis, N.C. (2015). Statistical Measures for Usage-Based Linguistics. Language Learning, 65, 1-28.

Griffiths, T. L. \& Kalish, M. L. (2007). Language Evolution by Iterated Learning with Bayesian Agents. Cognitive Science, 31, 441-480.

Guilloteaux, M. J., \& Dörnyei, Z. (2008). Motivating Language Learners: A Classroom-oriented Investigation of the Effects of Motivational Strategies on Student Motivation. TESOL Quarterly, 42, 55-77.

Guilloteaux, M. J., \& Dörnyei, D., Zoltán. (2009). Reply to Rod Ellis's Comment on “Motivating Language Learners: A Classroom-oriented Investigation of the Effects of Motivational Strategies on Student Motivation." TESOL Quarterly $43,109-111$.

Hagen, L.K. (2008). The Bilingual Brain: Human Evolution and Second Language Acquisition. Evolutionary Psychology, 6, 43-63.

Hauser, M., Chomsky, N. \& Fitch, W. T. (2002). The Language Faculty: What is It, Who Has It, and How Did It Evolve? Science, 29, 1569-1579.

Hauser, M.D, Yang, C., Berwick, R.C., Tattersall, I., Ryan, M.J., Watumull, J., Chomsky, N. \& Lewontin, R. (2014). The Mystery of Language Evolution. Frontiers in Psychology, 5, 401 doi:10.3389/fpsyg.2014.00401. 
Hernandez, A.E., Hofmann, J. \& Kotz, S.A. (2007). Age of Acquisition Modulates Neural Activity for Both Regular and Irregular Syntactic Functions. Neuroimage, 36, 912-923.

Hefling, I, Dilharreguy, B., Bordessoules, M. \& Allard, M. (2012). The Neural Processing of Second Language Comprehension Modulated by the Degree of Proficiency: A Listening Connected Speech fMRI Study. The Open Neuroimaging Journal, 6, 44-54.

Hills, T.T. \& Adelman, J.S. (2015). Recent Evolution of Learnability in American English from 1800 to 2000. Cognition, 143, 87-92.

Hoffmann, T \& Trousdale. G. (2013). Variation, Change and Constructions in English. Cognitive Linguistics, 22, 1-23

Höhle, B. (2009). Bootstrapping Mechanisms in First Language Acquisition. Linguistics, 47, 359-382.

Hulstijn, J. H., Young, R. F., Ortega, L., Bigelow, M., DeKeyser, R., Ellis, N. C., Lantolf, J. P., Mackey, A., \& Talmy, S. (2014). Bridging the Gap: Cognitive and Social Approaches to Research in Second Language Learning and Teaching. Studies in Second Language Acquisition, 36, 361-421.

Kemmerer, D. (2014). Neurolinguistics: Mind, Brain and Language. In: The Routledge Handbook of Linguistics. K. Allan (Ed.) New York: Routledge.

J. P., Jarvis, H. (2015). From PPP and CALL/ MALL to a Praxis of Task-based Teaching and Mobile Assisted Language Use. TESL-EJ 19.1.

Kemp, C. \& Regier, T. (2012). Kinship Categories Across Languages Reflect General Communicative Principles. Science, 336, 1049-1054.

Kimura, M. (1968). Evolutionary Rate at the Molecular Level. Nature, 217, 624-626.

Kirby, S. \& Christiansen, M.H. (2003). From Language Evolution to Language Learning. In: Language Evolution. M. Christiansen \& S. Kirby (Eds) Oxford: Oxford University Press

Kirby, S. Griffiths, T. \& Smith, K. (2014). Iterated Learning and the Evolution of Language. Current Opinions in Neurobiology, 28, 108-114.

Kirby, S., Tameriz, M., Cornish, H. \& Smith, K. (2015). Compression and Communication in the Cultural Evolution of Linguistic Structure. Cognition, 141, 87-102.

Kirschner, P.A., Sweller, J. \& Clark, R.E. (2006). Why Minimal Guidance During Instruction Does Not Work: An Analysis of the Failure of Constructivist, Discovery, Problem-based, Experiential and Inquiry-based Teaching. Educational Psychology, 41, 75-86.

Kuhl, P.K. (2011). Early Language Learning and Literacy: Neuroscience Implications for Education. Mind, Brain and Education, 5, 128-142.

Lachlan, R.F. \& Feldman, M.W. (2003). Evolution of Cultural Communication Systems: The Coevolution of Cultural Signals and Genes Encoding Learning Preferences. Journal of Evolutionary Biology, 16, 1084-1095.

Landsbergen, F., Lachlan, R., Ten Cate, C. \& Verhagen, A. (2010). A Cultural Evolutionary Model of Patterns in Semantic Change. Linguistics, 48, 363-390.

Lewis, M. (1996). Implications of a Lexical View of Language. In: D Willis \& J Willis (Eds) Challenge and Change in Language Teaching. Oxford: MacMillan Heinemann

Lewontin, R.C. (2014). The Mystery of Language Evolution. Frontiers in Psychology, 5, 401. doi: 10.3389/fpsyg.2014.00401.

Lieberman, P. (2007). The Evolution of Human Speech its Anatomical and Neural Base. Current Anthropology, 48, 3966.

Littlewood, W. (2004). The Task-based Approach: Some Questions and Suggestions. English Language Teaching Journal, 58, 319-326.

Mackey, A. (2006). Feedback, Noticing and Instructed Second Language Learning. Applied Linguistics, 27, 405-430.

Mackey, A., \& Talmy, S. (2014). Bridging the Gap: Cognitive and Social Approaches to Research in Second Language Learning and Teaching. Studies in Second Language Acquisition, 36, 361-421.

McEowna, M.S. \& Takeuchib, O. (2010). What Can Teachers Do to Motivate their Students? A Classroom Research on Motivational Strategy Use in the Japanese EFL Context. Innovation in Language Learning and Teaching, 4, 21-35.

McEowna, M.S. \& Takeuchib, O. (2014). MotivationalSstrategies in EFL Classrooms: How Do Teachers Impact Students' Motivation? Innovation in Language Learning and Teaching, 8, 20-38.

Misyak, J.B., Christiansen, M.H. \& Tomblin, J.B. (2010). Sequential Expectations: The Role of Prediction-based Learning in Language. Topics in Cognitive Science, 2, 138-153.

Morgan-Short, K., Finger, I., Grey, S. \& Ullman, M.T. (2012a). Second Language Processing Shows Increased Nativelike Neural Responses after Months of No Exposure. PLoS ONE, 7, e32974. doi:10.1371/journal.pone.0032974.

Morgan-Short, K., Steinhauer, K., Sanz, C. \& Ullman, M., T. (2012b). Explicit and Implicit Second Language Training Differentially Affect the Achievement of Native-like Brain Activation Patterns. Journal of Cognitive Neuroscience, 24, 933-947.

Morgan-Short, K. Faretta-Stutenberg, M., Brill-Schuetz, K.A., Carpenter, H., Wong, P.M.C. (2014). Declarative and Procedural-memory as Individual Differences in Second Language Acquisition. Bilingualism Language and Cognition, $17,56-72$.

Ortaçtepe, D. (2013). Formulaic Language and Conceptual Socialization: The Route to Becoming Native Like in L2. System, 41, 852-865. 
Oxford, R. (2006). Task Based Language Teaching: An Over View Asian EFL Journal, 8, 9-94.

Pae, T.I. (2008). Second Language Orientation and Self-Determination Theory: A Structural Analysis of the Factors Affecting Second Language Achievement Journal of Language and Social Psychology, 27, 5-27.

Perani, D., Abutalebi, J., Paulesu, E. \& Brambati, S. (2003). The Role of Age of Acquisition and Language Usage in Early, High-proficient Bilinguals: An fMRI Study During Verbal Fluency. Human Brain Mapping, 19, 170-182.

Pérez, A., Dowens, M.G., Molinaro, N., Iturria-Medina, Y. \& Barraza, P., García-Pentón, L., Carreiras, M. (2015). Complex Brain Network Properties in Late L2 Learners and Native Speakers. Neuropsychologia, 68, 209-217.

Perfors, A. \& Navarro, D.J. (2014). Language Evolution Can Be Shaped by the Structure of the World. Cognitive Science, 38, 775-793.

Piantadosi, S.T., Tily, H. \& Gibson, E. (2012). The Communicative Function of Ambiguity in 1Language. Cognition, 122, 280-91.

Pleyer, M. \& Winters, J. (2014). Integrating Cognitive Linguistics and Language Evolution Research. Theoria et Historia Scientiarum, 11, 19-43.

Poeppel, D., Emmorey, K. Hickok, G. \& Pylkkänen, L. (2012). Towards a New Neurobiology of Language. Journal of Neuroscience, 32, 14125-14131.

Puig, M. V., Rose, J., Schmidt, R. \& Freund, N. (2014). Dopamine Modulation of Learning and Memory in the Prefrontal Cortex: Insights from Studies in Primates, Rodents, and Birds. Frontiers in Neural Circuits, 8, doi 10.3389/fncir.2014.00093.

Ritchie, G. (2003). Presentation-Practice-Production and Task-Based Learning in the Light of Second Language Learning Theories. English Teacher: An International Journal, 6, 112-124.

Robenalt, C. \& Goldberg, A.E. (2015). Judgment Evidence for Statistical Preemption: It Is Relatively Better to Vanish than to Disappear a Rabbit, but a Lifeguard Can Equally Well Backstroke or Swim Children to Shore. Cognitive Linguistics, 26, 467-503.

Scheffner Hammer, C., Hoff, E., Uchikoshi, Y. Gillanders, C., Castro, D. \& Sandilo, L.E. (2014). The Language and Literacy Development of Young Dual Language Learners: A Critical Review. Early Childhood Research Quarterly, 29, 715-733.

Schmidt, R. (1990). The Role of Consciousness in Second Language Learning. Applied Linguistics, 11, 129-158.

Serrano, R., Stengers, H. \& Housen, A. (2014). Acquisition of Formulaic Sequences in Intensive and Regular EFL Programmes. Language Teaching Research, 19, 89-106.

Skehan, P. (2003). Task-based Instruction. Language Teaching, 36, 1-14.

Smith, K. (2004). The Evolution of Vocabulary. Journal of Theoretical Biology, 228, 127-142.

Smith, K. Brighton, H, \& Kirby, S. (2003). Complex Systems in Language Evolution: The Cultural Emergence of Compositional Structure. Advance Complex Systems, 6, 1-22.

Smith, K. \& Kirby, S. (2008). Cultural Evolution: Implications for Understanding the Human Language Faculty and Its Evolution. Philosophical Transactions of the Royal Society B, 363, 3591-3603.

Smith, K., Tamariz, M. \& Kirby, S. (2013). Linguistic Structure Is an Evolutionary Trade-off Between Simplicity and Expressivity. In: M. Knauff, M. Pauen, N. Sebanz, \& I. Wachsmuth (Eds.), Proceedings of the 35th Annual Conference of the Cognitive Science Society (pp. 1348-1353). Austin, TX: Cognitive Science Society.

Sousa, D.A. (2011). How the Brain Learns. (4 ${ }^{\text {th }}$ Ed) CA: Corwin.

Steels, L. (2011). Modelling the Cultural Evolution of Language. Physics of Life Reviews, 8, 339-356.

Stout, D. \& Chaminade, T. (2012). Stone Tools, Language and the Brain in Human Evolution. Philosophical Transactions of the Royal Society B, 367, 75-87.

Tamariz M, Ellison TM, Barr DJ, Fay N. (2014). Cultural Selection Drives the Evolution of Human Communication Systems. Proceedings of the Royal Society B, 281, 20140488. http://dx.doi.org/10.1098/rspb.2014.0488.

Thurman, J. (2013). Choice and Its Influence on Intrinsic Motivation and Output in Task-based Language Teaching. The Asian EFL Journal Quarterly, 15, 202-245.

Tokuhama-Espinosa, T. (2009). The New Science of Teaching and Learning: Using the Best of Mind, Brain, and Education Science in the Classroom. NY: Economic Policy Institute and Teachers College.

Tomasello, M. (2008). The Usage Based Theory of Language Acquisition. In: The Cambridge Handbook of Child Language. (E.I. Bavin Ed.) Cambridge: Cambridge University Press

Trousdale, G., \& Hoffmann, T. (Eds) (2013). Oxford Handbook of Construction Grammar. Oxford: Oxford University Press.

Waninge, F, Dörnyei, Z. \& De Bot, K. (2014). Motivational Dynamics in Language Learning: Change, Stability, and Context. Modern Language Journal, 98, 704-723.

Warden, C.A. \& Lin, H.J. (2000). Existence of Integrative Motivation in an Asian EFL Setting Foreign Language Annals, 33, 535-545.

Willis, J. and Willis, D. (1996). (Eds.) Challenge and Change in Language Teaching. Oxford: MacMillan Heinemann Wray, A. (2000). Formulaic Sequences and Second Language Teaching: Principle and practice. Applied Linguistics, 21, 463-489.

Wray, A. (2012). What Do We (think we) Know about Formulaic Language? An Evaluation of the Current State of Play. Annual Review Applied Linguistics, 32, 231-254 
Wong, R.M.H. (2012). Motivation to Learn English and School Grade Level: The Case of Newly Arrived Hong Kong Students Porta Linguarum, 21, 37-50

Wong, P.C.M., Morgan-Short, K., Ettlinger, M. \& Zhen, J. (2012). Linking Neurogenetics and Individual Differences in Language Learning: The Dopamine Hypothesis. Cortex, 48, 1091-1102

Wong P.C.M., Ettlinger, M. \& Zheng, J. (2013). Linguistic Grammar Learning and DRD2-TAQ-IA Polymorphism PLoS ONE, 8, e64983. doi:10.1371/ journal.pone.0064983

Yang, J, Gates, K.M., Molenaar, P. \& Li, P. (2014). Neural Changes Underlying Successful Second Language Word Learning: An fMRI Study. Journal of Neurolinguistics, 33, 29-34. 